\title{
Antidiabetic Potential of Flavones on Streptozotocin-induced Diabetes Mellitus in Rat
}

\author{
Binish Inam ${ }^{1}$, Adil Inam ${ }^{1}$, Monika Verma², Kamlesh Kumar Naik ${ }^{3}$, Afroze Alam ${ }^{4,5 *}$ \\ 'Department of Community Medicine, Narayan Medical College and Hospital, Jamuhar, Sasaram-Rohtas, Bihar, INDIA. \\ 2Department of Paediatrics, Advanced Paediatrics Centre - PGIMER, Chandigarh, Punjab, INDIA. \\ ${ }^{3}$ Department of Pharmaceutical Chemistry, Nandha College of Pharmacy, Perundurai, Main Road, Erode, Tamil Nadu, INDIA. \\ ${ }^{4}$ Narayan Institute of Pharmacy, Gopal Narayan Singh University, Jamuhar, Rohtas (Sasaram), Bihar, INDIA. \\ ${ }^{5}$ School of Pharmacy, Al-Karim University, Katihar-Purnia Road, Sirsa, Karim Bagh, Katihar, Bihar, INDIA.
}

\begin{abstract}
Objectives: The objective of the study was to develop new antidiabetic agents from synthetic route. Methods: An attempt was made to synthesize various flavones. The structures of the compounds were elucidated by $U V, I R,{ }^{1} H-N M R$ and mass spectrometry. Furthermore, an in vivo antidiabetic activity study was carried out by streptozotocin induced model. Biochemical parameters were extensively studied to support anti-diabetic potential of synthesized flavones. Results: The study reveals that flavones such as F1, F2, F3, F5 and F8 were potentially considered for in-vivo antidiabetic activity. Fasting blood glucose and biochemical parameters like total protein, urea and creatinine, SGOT, SALP and SGPT were performed for the biological evaluation and compared with that of standard glibenclamide $(5 \mathrm{mg} / \mathrm{kg}$ ). Among the five consolidated flavones, F8 possess high significant $(p<0.01)$ results and restores the blood glucose level, liver enzymes and renal parameters. Based on these results, a promising potent drug
\end{abstract}

would be developed in the management of diabetes mellitus. Conclusion: In-vivo evaluations of selected compounds were carried out for its antidiabetic activity considering different biochemical parameters. Some of the selected flavones showed excellent and noticeable antidiabetic activity. Key words: Antidiabetic activity, Creatinine, Flavones, Total Protein, SGOT, SALP, SGPT, Streptozotocin

\section{Correspondence}

Dr. Afroze Alam,

Narayan Institute of Pharmacy, Jamuhar-821305, (Rohtas) Sasaram, Bihar, INDIA.

Phone no: +91-7018196843

Email: afrozepharma@gmail.com

DOI: 10.5330/ijpi.2019.4.36

\section{INTRODUCTION}

Diabetic mellitus is a metabolic disorder, which is characterised by improper secretion or utilisation of insulin, results in hyperglycaemia. ${ }^{1}$ As per WHO report, diabetic mellitus is an one of the leading cause of death in $2030^{2}$ and it clearly assessed that $1.5-4.9$ million people were death from 2012 to 2014. According to the current scenario, the development of hypoglycaemic drugs in the management of diabetes, as well as in the prevention of diabetic complication should be a challenging one in clinical importance.

The naturally available flavonoid plays vital role in treating so many major diseases, in that one of the chronic disease is diabetes mellitus. Basically, flavonoids and its classes bears low molecular weight, which exists various biodynamic properties such as antioxidant, antimicrobial activity, anti-allergic, anti-inflammatory, hepatoprotective, antimutagenic effects and also inhibit various enzymes. ${ }^{3-9}$

There are many herbal extracts having reported anti-diabetic potentials. ${ }^{10}$ Among these phytochemicals, flavonoids and their related natural compounds are known to possess anti-diabetic activity, established in various animal models. ${ }^{11}$ Flavonoids are the most common polyphenolic compounds used as medicaments for diabetes mellitus since ancient times. ${ }^{12,13}$ One of the ways to reduce type II diabetes mellitus is by suppressing absorption and digestion of dietary carbohydrates.

The current study deals with the evaluation of the inhibitory activity of flavone as potential antidiabetic agents. Based on the result flavones were evaluated for in vivo antidiabetic activity by inducing streptozotocin in Wister rats. Streptozotocin is selectively used as a toxicant compared with alloxan to produce diabetes by destruction of $\beta$ cells on islet of
Langerhans. ${ }^{14}$ By which blood glucose level, liver and renal parameters were evaluated and compared with standard drug on treated rats. Hence the present study deals on development of potent drug in the management of diabetes mellitus.

\section{MATERIALS AND METHODS}

\section{Chemical and Reagents}

Substituted acetophenones, aromatic aldehydes and Streptozotocin (STZ) were purchased from SRL Pvt. Ltd, Mumbai, Hi-media Pvt. Ltd, Mumbai and Loba Chemicals, Cochin. The solvents and other reagents and kits were purchased commercially and were of analytical grade.

\section{Scheme of Synthesis}

The scheme of this synthesis is based on Algar-Flynn-Oyamada method for the synthesis of flavones (F1-F10). ${ }^{15-17}$



This is an open access article distributed under the terms of the Creative Commons Attribution-NonCommercial-ShareAlike 4.0 License, which allows others to remix, tweak, and build upon the work non-commercially, as long as the author is credited and the new creations are licensed under the identical terms. 
$\mathrm{R}_{1}=\mathrm{H}, \mathrm{R}_{2}=-\mathrm{C}_{6} \mathrm{H}_{5,} \mathrm{C}_{6} \mathrm{H}_{4}-2(\mathrm{Cl}),-\mathrm{C}_{6} \mathrm{H}_{4}-4(\mathrm{Cl}),-\mathrm{C}_{6} \mathrm{H}_{4}-4(\mathrm{~F}),-\mathrm{C}_{6} \mathrm{H}_{4}-2\left(\mathrm{NO}_{2}\right)$, $-\mathrm{C}_{6} \mathrm{H}_{4}-2(\mathrm{OH}),-\mathrm{C}_{6} \mathrm{H}_{4}-4(\mathrm{OH}),-\mathrm{C}_{6} \mathrm{H}_{4}-4\left(\mathrm{OCH}_{3}\right),-\mathrm{C}_{6} \mathrm{H}_{4}-2,4\left(\mathrm{OCH}_{3}\right),-\mathrm{C}_{6} \mathrm{H}_{4}-$ $\mathrm{N}\left(\mathrm{CH}_{3}\right)_{2}$

\section{Determination on Anti-Diabetic Activity}

\section{Animals}

Male albino Wister rats (150 - $200 \mathrm{~g}$ body weight) were obtained from College of Veterinary and Animal Sciences, Thrissur, India and maintained under a constant $12 \mathrm{hr}$ light and dark cycle at $21-23^{\circ} \mathrm{C}$. The animals were maintained in accordance with the guidelines of the National Institute of Nutrition, Hyderabad, India. The study was approved by the Institutional Ethics Committee Reg.no: 718/PO/Rd/S/04/CPCSEA. Throughout the experimental period, all four groups of animals were fed with a normal laboratory chow standard pellet diet (Sai feeds, Bangalore, India) and water ad libitum.

\section{Induction of Diabetes}

Animals were allowed fasting for $12 \mathrm{hr}$ and administered freshly prepared Streptozotocin (STZ) (Himedia) at the concentration of $60 \mathrm{mg} /$ $\mathrm{kg}$ bodyweight, ${ }^{18}$ i.p. in $0.1 \mathrm{~mol} / \mathrm{L}$ cold citrate buffer, $\mathrm{pH} 4.5$. The STZtreated animals were allowed to drink $5 \%$ glucose solution overnight to overcome drug-induced hypoglycemia. Rats having persistent glycosuria and hyperglycaemia with a fasting blood glucose $>250 \mathrm{mg} / \mathrm{dL}$ on the third day after the STZ injection were considered as diabetic and use for further experimentation.

\section{Experimental design}

Animals were divided into 8 groups, consisting of a minimum of four animals each as follows: Group I, control rats received $0.1 \mathrm{~mol} / \mathrm{L}$ citrate buffer ( $\mathrm{pH} 4.5$ ); Group II, diabetic control; Group III, IV, V, VI and VII diabetic rats were administered with synthesized compounds F1, F2, F3, F5 and F8 for 21 days. Group VIII, diabetic rats were administered $5 \mathrm{mg} /$ $\mathrm{kg}$ glibenclamide solution orally per day for 21 days.

After one week the induction of diabetes in Wistar rats, the fasting blood glucose levels of fasted rats were measured. Rats with blood glucose $>$ $250 \mathrm{mg} / \mathrm{dl}$ were considered as diabetes in this study. The different doses of synthesized flavonoids were administered every day till the completion of the experiment (i.e., 21 days), whereas untreated and diabetic control groups were treated with $0.1 \mathrm{~mol} / \mathrm{L}$ citrate buffer every day orally. At the end of the experiment, the blood samples were collected for biochemical studies. The serum were separated by centrifugation and subjected for assay immediately or stored at $-20^{\circ} \mathrm{C}$.

\section{Biochemical Estimations}

Blood were collected from the tail vein of the overnight fasting rat at $0^{\text {th }}$ (before the start of the experiment), $4^{\text {th }}$ day, $7^{\text {th }}$ day, $14^{\text {th }}$ day and $21^{\text {st }}$ day. The glucose levels were estimated by using Accu-Check Active glucometer. Weight of individual animals was measured gravimetrically on $0^{\text {th }}$ and $21^{\text {st }}$ days of the experiment. After the experimental regimen, the blood were collected through the retro-orbital puncture of eye of animals under mild diethyl ether anaesthesia in Eppendorff's tube $(1 \mathrm{ml})$ Containing $50 \mu \mathrm{l}$ of anticoagulant (10\% trisodium citrate) and serum was separated by Centrifugation at $3000 \mathrm{rpm}$ for $15 \mathrm{~min}$. The biochemical parameters of liver such as SGPT, SGOT, SALP and Serum bilirubin were determined by using the Commercial kit available ${ }^{19}$ (Ecoline, manufactured by Merck specialities, private Limited, Ambernath) and renal parameters such as Protein, ${ }^{20}$ creatinine ${ }^{21}$ and serum urea. ${ }^{22}$ Measure the values using Auto Analyzer.

\section{Statistical analysis}

Data obtained from pharmacological experiments, are expressed as mean \pm SEM. Differences between control and treated groups were tested for significance using ANNOVA followed by Dunnett's $t$-test, with $P$ $<0.05$ were considered as significant.

\section{RESULTS}

\section{Spectral Analysis}

All the synthesized compounds were characterized by various spectroscopic techniques such as UV, IR, ${ }^{1} \mathrm{H}-\mathrm{NMR}$ and mass spectrometry.

\section{F1: 2-phenyl-4H-chromen-4-one}

MP: $130-132^{\circ} \mathrm{C} ; \mathrm{R}_{f}=0.56 ; \%$ yield $=65.3 \% \mathrm{w} / \mathrm{w} ; \mathrm{UV} \lambda_{\max }: \mathrm{CHCl}_{3}, \mathrm{~nm}: 297$; IR ( $\left.\mathrm{KBr} \mathrm{cm}{ }^{-1}\right): 1739$ (lactone), 1643 (CO str), 1585, 1550 (C=C Arom. str), 1134, 1093 (COC str), 771 (C-C bending); ${ }^{1} \mathrm{H}$ NMR (500 MHZ, DMSO): $\delta 7.4-7.9(\mathrm{~m}, 8 \mathrm{H}, \operatorname{ArH}), 6.9(\mathrm{~m}, 1 \mathrm{H}, \operatorname{ArH}) ; \mathrm{m} / \mathrm{z}: 222(\mathrm{~m}+1)$, 120.7 $\left(\mathrm{C}_{7} \mathrm{H}_{6} \mathrm{O}_{2}\right)^{+}, 105.8\left(\mathrm{C}_{7} \mathrm{H}_{8}\right)^{+}, 92.8\left(\mathrm{C}_{6} \mathrm{H}_{6} \mathrm{O}\right)^{+}, 77.9\left(\mathrm{C}_{6} \mathrm{H}_{5}\right)^{+}$.

\section{F2: 3-(2-chlorophenyl)-4H-1-benzopyran-4-one}

MP: $157-160^{\circ} \mathrm{C} ; \mathrm{R}_{f}=0.3 ; \%$ yield $=42.4 \% \mathrm{w} / \mathrm{w} ; \mathrm{UV} \lambda_{\max }: \mathrm{CHCl}_{3}, \mathrm{~nm}$ : 241; IR ( $\mathrm{KBr} \mathrm{cm}^{-1}$ ): 1797 (lactone), 1687 (CO str), 1593, 1564 (C=C Arom.str), 1124, 1103, 1037 (COC str), 754 (C-C bending); ${ }^{1} \mathrm{H}$ NMR (500 MHZ, DMSO): $\delta ; 6.6(\mathrm{~m}, 1 \mathrm{H}, \mathrm{ArH}), 7.4-7.8$ (m, 8H, ArH); m/z: $256(\mathrm{~m}+1), 138.9\left(\mathrm{C}_{8} \mathrm{H}_{7} \mathrm{Cl}\right)^{+}, 120.9\left(\mathrm{C}_{7} \mathrm{H}_{6} \mathrm{O}_{2}\right)^{+}, 91.9\left(\mathrm{C}_{6} \mathrm{H}_{5} \mathrm{O}\right), 77\left(\mathrm{C}_{6} \mathrm{H}_{5}\right)^{+}$.

F3: 3-(4-chlorophenyl)-4H-1-benzopyran-4-one

MP: $167-170^{\circ} \mathrm{C} ; \mathrm{R}_{f}=0.84 ; \%$ yield $=40.4 \% \mathrm{w} / \mathrm{w} ; \mathrm{UV} \lambda_{\max }: \mathrm{CHCl}_{3}, \mathrm{~nm}$ : 261

IR ( $\left.\mathrm{KBr} \mathrm{cm}{ }^{-1}\right) 1735$ (lactone), 1685 (CO str), 1593, 1573 (C=C Arom. str), 1130, 1091 (COC str), 761 (C-C bending); ${ }^{1} \mathrm{H}$ NMR (500 MHZ, DMSO): $\delta 7.4-7.9(\mathrm{~m}, 8 \mathrm{H}, \operatorname{ArH}), 6.7(\mathrm{~m}, 1 \mathrm{H}, \operatorname{ArH}) ; \mathrm{m} / \mathrm{z}: 256(\mathrm{~m}+1)$, 121.6 $\left(\mathrm{C}_{7} \mathrm{H}_{6} \mathrm{O}_{2}\right)^{+}, 139.5\left(\mathrm{C}_{8} \mathrm{H}_{7} \mathrm{Cl}\right)^{+}, 76.6\left(\mathrm{C}_{6} \mathrm{H}_{5}\right)^{+}$.

\section{F4: 2-(4-fluorophenyl)-4H-chromen-4-one}

MP: $241-243^{\circ} \mathrm{C} ; \mathrm{R}_{f}=0.85 ; \%$ yield $=59.3 \% \mathrm{w} / \mathrm{w} ; \mathrm{UV}_{\lambda \max }: \mathrm{CHCl}_{3}, \mathrm{~nm}$ : 250; IR ( $\mathrm{KBr} \mathrm{cm}^{-1}$ ): 1772 (lactone), 1685 (CO str), 1577, 1514 (C=C Arom.str), 1126, 1107, 1024 (COC str), 773 (C-C bending); ${ }^{1} \mathrm{H}$ NMR (500 MHZ, DMSO): $\delta 6.9(\mathrm{~m}, 1 \mathrm{H}, \mathrm{ArH}), 7.6-8.6(\mathrm{~m}, 8 \mathrm{H}, \mathrm{ArH}) ; \mathrm{m} / \mathrm{z}$ : $240(\mathrm{~m}+1), 122\left(\mathrm{C}_{7} \mathrm{H}_{6} \mathrm{O}_{2}\right)^{+}, 119.5\left(\mathrm{C}_{8} \mathrm{H}_{6} \mathrm{~F}\right)^{+}, 75.5\left(\mathrm{C}_{6} \mathrm{H}_{3}\right)^{+}$.

\section{F5: 3-(2-nitrophenyl)-4H-1-benzopyran-4-one}

MP: $145-148^{\circ} \mathrm{C} ; \mathrm{R}_{f}=0.43 ; \%$ yield $=51.6 \% \mathrm{w} / \mathrm{w} ; \mathrm{UV} \lambda_{\max }: \mathrm{CHCl}_{3}, \mathrm{~nm}$ : 306; IR ( $\mathrm{KBr} \mathrm{cm}^{-1}$ ): 1797 (lactone), 1681 (CO str), 1593, 1573 (C=C Arom.str), 1128, 1091 (COC str), 761 (C-C bending); ${ }^{1} \mathrm{H}$ NMR (500 MHZ, DMSO): $\delta 7.4-7.6$ (m, 8H, ArH), $6.2(\mathrm{~m}, 1 \mathrm{H}, \mathrm{ArH}) ; \mathrm{m} / \mathrm{z}: 267$ $(\mathrm{m}+1), 121.1\left(\mathrm{C}_{7} \mathrm{H}_{6} \mathrm{O}_{2}\right)^{+}, 148.9\left(\mathrm{C}_{8} \mathrm{H}_{7} \mathrm{NO}_{2}\right)^{+}, 76.9\left(\mathrm{C}_{6} \mathrm{H}_{5}\right)^{+}$.

\section{F6: 2-(2-hydroxyphenyl)-4H-chromen-4-one}

MP: $185-188^{\circ} \mathrm{C} ; \mathrm{R}_{f}=0.58 ; \%$ yield $=47.2 \% \mathrm{w} / \mathrm{w} ; \mathrm{UV} \lambda_{\max }: \mathrm{CHCl}_{3}, \mathrm{~nm}$ : 248; IR ( $\mathrm{KBr} \mathrm{cm}^{-1}$ ): 1734 (lactone), 1683 (CO str), 1558, 1541 (C=C Arom.str), 1139, 1093 (COC str), 765 (C-C bending) 3566, $3547(\mathrm{OH}$ str); ${ }^{1} \mathrm{H}$ NMR (500 MHZ, DMSO): $\delta 6.5(\mathrm{~m}, 1 \mathrm{H}, \mathrm{ArH}), 7.1-7.9(\mathrm{~m}, 8 \mathrm{H}$, ArH); m/z: $238(\mathrm{~m}+1), 121\left(\mathrm{C}_{7} \mathrm{H}_{6} \mathrm{O}_{2}\right)^{+}, 106\left(\mathrm{C}_{7} \mathrm{H}_{6} \mathrm{O}\right)^{+}, 104\left(\mathrm{C}_{8} \mathrm{H}_{8}\right)^{+} 78$ $\left(\mathrm{C}_{6} \mathrm{H}_{6}\right)^{+}$.

\section{F7: 2-(4-hydroxyphenyl)-4H-chromen-4-one}

MP: $181-183^{\circ} \mathrm{C} ; \mathrm{R}_{f}=0.41 ; \%$ yield $=47.5 \% \mathrm{w} / \mathrm{w} ; \mathrm{UV} \lambda_{\max }: \mathrm{CHCl}_{3}, \mathrm{~nm}$ : 287; IR ( $\left.\mathrm{KBr} \mathrm{cm}^{-1}\right): 1772$ (lactone), 1691 (CO str), 1560, 1543, 1516 (C=C Arom.str), 1047, 1139 (COC str), 748 (C-C bending) 3300, $3545(\mathrm{OH}$ str); ${ }^{1} \mathrm{H}$ NMR(500 MHZ, DMSO): $\delta 6.8(\mathrm{~m}, 1 \mathrm{H}, \mathrm{ArH}), 7.7-7.4(\mathrm{~m}, 8 \mathrm{H}$, $\mathrm{ArH}) ; \mathrm{m} / \mathrm{z}: 238(\mathrm{~m}+1), 121\left(\mathrm{C}_{7} \mathrm{H}_{6} \mathrm{O}_{2}\right)^{+}, 118\left(\mathrm{C}_{8} \mathrm{H}_{7} \mathrm{O}\right)^{+}, 92\left(\mathrm{C}_{6} \mathrm{H}_{6} \mathrm{O}\right)^{+}, 76.9$ $\left(\mathrm{C}_{6} \mathrm{H}_{6}\right)^{+}$. 
Table 1: Effect of synthesized flavones on blood glucose level on STZ induced diabetic rats.

\begin{tabular}{ccccc}
\hline \multirow{2}{*}{ GROUPS } & \multicolumn{3}{c}{ Fasting Blood Glucose Level (mg/dl) } \\
\cline { 2 - 4 } & $1^{\text {st }}$ day & $7^{\text {th }}$ day & $14^{\text {th }}$ day & $21^{\text {st }}$ day \\
\hline Normal Control & $94.23 \pm 2.03$ & $97 \pm 2.65$ & $96 \pm 2.65$ & $96.13 \pm 1.16$ \\
Diabetic Control & $267.43 \pm 3.53^{* *}$ & $283.35 \pm 2.40^{* *}$ & $313.22 \pm 2.91^{* *}$ & $318.46 \pm 4.33^{* *}$ \\
Standard & $253.66 \pm 3.18^{*}$ & $191.66 \pm 2.03^{* *}$ & $158 \pm 3.46^{* *}$ & $122.66 \pm 4.98^{* *}$ \\
F1 & $255.66 \pm 2.33^{*}$ & $203.67 \pm 4.96^{* *}$ & $167.33 \pm 4.09^{* *}$ & $124.33 \pm 2.90^{* *}$ \\
F2 & $259.33 \pm 2.60$ & $276.58 \pm 2.85$ & $302.62 \pm 3.48^{*}$ & $311.37 \pm 2.73^{*}$ \\
F3 & $257.23 \pm 3.53$ & $276.27 \pm 3.48$ & $305.46 \pm 4.33^{*}$ & $309.18 \pm 3.57^{*}$ \\
F5 & $268.39 \pm 5.17$ & $275.67 \pm 4.82^{*}$ & $301.69 \pm 4.27^{*}$ & $313.13 \pm 3.74$ \\
F8 & $253.24 \pm 3.46^{*}$ & $199.24 \pm 2.31^{* *}$ & $171.33 \pm 3.45^{* *}$ & $127.33 \pm 4.72^{* *}$ \\
\hline
\end{tabular}

Values are mean $\pm \operatorname{SEM}(n=4) ;{ }^{* *} P<0.01$ as compared with normal control; ${ }^{*} P<0.05 ;{ }^{* *} P<0.01$ as compared with diabetic control.

Table 2: Effect of synthesized flavones in Liver biomarker enzymes and total protein on STZ induced diabetic rats.

\begin{tabular}{cccccc}
\hline Groups & SGOT (IU/I) & SGPT (IU/l) & SALP (IU/I) & Total bilirubin (mg/dl) & $\begin{array}{c}\text { Total Protein } \\
\text { (g/dl) }\end{array}$ \\
\hline $\begin{array}{c}\text { Normal control } \\
\text { Diabetic } \\
\text { control }\end{array}$ & $54.33 \pm 1.20$ & $25.20 \pm 1.73$ & $102.33 \pm 5.18$ & $0.49 \pm 0.02$ & $6.93 \pm 0.02$ \\
Standard & $126.15 \pm 5.16^{* *}$ & $54.38 \pm 1.53^{* *}$ & $228.31 \pm 9.46^{* *}$ & $3.94 \pm 0.23^{* *}$ & $4.87 \pm 0.07^{* *}$ \\
F1 & $52.54 \pm 1.21^{* *}$ & $29.81 \pm 2.43^{* *}$ & $118.13 \pm 6.52^{* *}$ & $0.94 \pm 0.02^{* *}$ & $6.51 \pm 0.03^{* *}$ \\
F2 & $77.36 \pm 4.74^{* *}$ & $33.25 \pm 2.08^{* *}$ & $124.52 \pm 8.13^{* *}$ & $1.43 \pm 0.08^{* *}$ & $6.12 \pm 0.21^{* *}$ \\
F3 & $122.14 \pm 5.34$ & $48.66 \pm 3.78^{*}$ & $221.33 \pm 9.51$ & $3.88 \pm 0.26$ & $4.73 \pm 0.15$ \\
F5 & $121.56 \pm 4.16^{*}$ & $52.23 \pm 3.17$ & $209.66 \pm 8.82^{*}$ & $3.50 \pm 0.28$ & $4.80 \pm 0.31$ \\
F8 & $123.34 \pm 2.64$ & $50.56 \pm 4.18$ & $216.33 \pm 9.38$ & $3.68 \pm 0.28$ & $4.77 \pm 0.28$ \\
\hline
\end{tabular}

Values are mean $\pm \operatorname{SEM}(n=4) ;{ }^{\sharp *} P<0.01$ as compared with normal control; ${ }^{*} P<0.05 ;{ }^{* *} P<0.01$ as compared with diabetic control.

\section{F8: 3-(4-methoxyphenyl)-4H-1-benzopyran-4-one}

MP: $175-177^{\circ} \mathrm{C} ; \mathrm{R}_{f}=0.43 ; \%$ yield $=49.2 \% \mathrm{w} / \mathrm{w} ; \mathrm{UV} \lambda_{\max }: \mathrm{CHCl}_{3}, \mathrm{~nm}$ : 265; IR ( $\left.\mathrm{KBr} \mathrm{cm}^{-1}\right): 1658$ (CO str), 1597, 1550 (C=C Arom.str), 1126, 1064 (COC str), 727 (C-C bending); ${ }^{1} \mathrm{H}$ NMR (500 MHZ, DMSO): $\delta$ $3.8\left(\mathrm{~s}, \mathrm{OCH}_{3}, \mathrm{ArH}\right), 6.4(\mathrm{~m}, 1 \mathrm{H}, \mathrm{ArH}), 7.0,7.8(\mathrm{~m}, 8 \mathrm{H}, \mathrm{ArH}) ; \mathrm{m} / \mathrm{z}: 252$ $(\mathrm{m}+1), 134.9\left(\mathrm{C}_{9} \mathrm{H}_{10} \mathrm{O}\right)^{+}, 107\left(\mathrm{C}_{7} \mathrm{H}_{6} \mathrm{O}\right)^{+}, 120.6\left(\mathrm{C}_{7} \mathrm{H}_{5} \mathrm{O}_{2}\right)^{+}, 77.0\left(\mathrm{C}_{6} \mathrm{H}_{5}\right)^{+}$.

\section{F9: 2-(2,4-dimethoxyphenyl)-4H-chromen-4-one}

MP: $178-180^{\circ} \mathrm{C} ; \mathrm{R}_{f}=0.6 ; \%$ yield $=46.4 \% \mathrm{w} / \mathrm{w} ; \mathrm{UV} \lambda_{\max }: \mathrm{CHCl}_{3}, \mathrm{~nm}$ : 250; IR ( $\mathrm{KBr} \mathrm{cm}^{-1}$ ): 1660 (CO str), 1597, 1550 (C=C Arom.str), 1124, 1066 (COC str), 752 (C-C bending); ${ }^{1} \mathrm{H}$ NMR(500 MHZ, DMSO): $\delta$ $3.8\left(\mathrm{~s}, \mathrm{OCH}_{3}, \mathrm{ArH}\right), 6.9$ (m, 1H, ArH), $7.0-7.7(\mathrm{~m}, 7 \mathrm{H}, \mathrm{ArH}) ; \mathrm{m} / \mathrm{z}: 283$ $(\mathrm{m}+1), 121\left(\mathrm{C}_{7} \mathrm{H}_{6} \mathrm{O}_{2}\right)^{+}, 92.7\left(\mathrm{C}_{6} \mathrm{H}_{6} \mathrm{O}\right)^{+}, 164\left(\mathrm{C}_{10} \mathrm{H}_{11} \mathrm{O}_{2}\right)^{+}, 137.5\left(\mathrm{C}_{8} \mathrm{H}_{10} \mathrm{O}_{2}\right)$ $+76.7\left(\mathrm{C}_{6} \mathrm{H}_{5}\right)^{+}$.

\section{F10: 2-[4-(dimethylamino)phenyl]-4H-chromen-4-one}

MP: $169-171^{\circ} \mathrm{C} ; \mathrm{R}_{f}=0.71 ; \%$ yield $=48.4 \% \mathrm{w} / \mathrm{w} ; \mathrm{UV} \lambda_{\max }: \mathrm{CHCl}_{3}, \mathrm{~nm}:$ 295; IR ( $\mathrm{KBr} \mathrm{cm}^{-1}$ ): 1795 (lactone), 1658 (CO str), 1548, 1537 (C=C Arom.str), 1124, 1064 (COC str), 727 (C-C bending); ${ }^{1} \mathrm{H}$ NMR(500 MHZ, DMSO): $\delta 2.4\left(\mathrm{~s}, 6 \mathrm{H}, \mathrm{N}\left(\mathrm{CH}_{3}\right)_{2}\right), 6.3$ - 6.5 (m, 1H, ArH), 7.5 - 7.9 $(\mathrm{m}, 8 \mathrm{H}, \mathrm{ArH}) ; \mathrm{m} / \mathrm{z}: 265(\mathrm{~m}+1), 222\left(\mathrm{C}_{15} \mathrm{H}_{10} \mathrm{O}_{2}\right)^{+}, 121\left(\mathrm{C}_{7} \mathrm{H}_{6} \mathrm{O}_{2}\right)^{+}, 104.9$ $\left(\mathrm{C}_{8} \mathrm{H}_{8}\right)^{+}, 77\left(\mathrm{C}_{6} \mathrm{H}_{5}\right)^{+}$.
Table 3: Effect of synthesised flavones in renal parameters on STZ induced diabetic rats.

\begin{tabular}{ccc}
\hline Groups & Blood urea $(\mathrm{mg} / \mathrm{dl})$ & Serum Creatinine $(\mathrm{mg} / \mathrm{dl})$ \\
\hline Normal control & $16.32 \pm 0.53$ & $0.68 \pm 0.03$ \\
Diabetic control & $31.72 \pm 2.01^{* *}$ & $0.98 \pm 0.08^{* *}$ \\
Standard & $19.36 \pm 1.45^{* *}$ & $0.72 \pm 0.05^{* *}$ \\
F1 & $25.33 \pm 1.67^{*}$ & $0.74 \pm 0.05^{* *}$ \\
F2 & $27.14 \pm 2.35$ & $0.96 \pm 0.02$ \\
F3 & $28.43 \pm 1.86$ & $0.92 \pm 0.06$ \\
F5 & $29.57 \pm 1.55$ & $0.91 \pm 0.04$ \\
F8 & $21.78 \pm 1.13^{* *}$ & $0.74 \pm 0.06^{* *}$ \\
\hline
\end{tabular}

Values are mean $\pm \operatorname{SEM}(n=4) ;{ }^{\# \#} P<0.01$ as compared with normal control; ${ }^{*} P$ $<0.05 ;{ }^{* *} P<0.01$ as compared with diabetic control.

\section{Biological Activity}

\section{Antidiabetic Activity}

The synthesised flavones (F1, F2, F3, F5 and F8) were subjected for pharmacological evaluation of anti-diabetic activity by streptozotocin induced rat model. The blood glucose level in rats was showed in the Table 1. The blood glucose level was highly significant $(p<0.01)$ compared to normal rats. After oral administration of synthesised flavones for 21 days were significantly reduced the blood glucose level compared with dia- 




Figure 1: Effect of synthesized flavones on BGL in Diabetic rats.



Figure2: Effect of synthesized flavones on Liver biomarker enzymes and total protein on STZ induced diabetic rats.

betic control rats. On $14^{\text {th }}$ and $21^{\text {st }}$ day the compounds, such as F1 F2, F3, F5 and F8 were significantly decreases $(p<0.01)$ the blood glucose level compared with diabetic control. It was evident from the table that diabetic control rats had elevated blood glucose level and the synthesised flavones were able to improve the metabolism significantly by comparing with the untreated rats see Figure 1, 2.

\section{Biochemical Parameters}

The liver parameters such as SGOT, SGPT, SALP and total bilurubin levels were increases in diabetic rats, which significantly $(p<0.01)$ restores the liver biomarker enzymes after treatment of synthesized flavones. The total protein level was decreases in diabetic rats and significantly increases after treatment of 21 days with synthesized flavones Table 2 . The renal parameters were showed in the Table 3 , which reveals that synthesized flavones restore the renal parameters such as blood urea and serum creatinine on STZ induced diabetic rats Table 3.

\section{DISCUSSION}

The focussed flavones were synthesized according to the protocol reported in the general scheme of synthesis. The percentage yields of the synthesized flavones were obtained moderately and melting point of those compounds were also recorded and presented uncorrectly. The purity of the each synthesized compounds were determined by thin layer chromatography using silica gel G plate as an stationary phase and hexane, ethyl acetate as mobile phase. The single spot was obtained, which indicate the pure state of the compound. The physico chemical parameters of all synthesized compounds were presented in the Table 1. Further, the focussed compounds were characterized by UV, IR, GCMS and ${ }^{1} \mathrm{H}$ NMR spectroscopy. Based on the results of above, the structure of synthesized compounds were proved and free from impurities.



Figure 3: Effect of Synthesized flavones in Renal Parameters on STZ induced diabetic rats

Diabetes Mellitus is a metabolic disorder and one of the most common chronic diseases. As per WHO report, it is the $5^{\text {th }}$ leading cause of death after twenty years. It is also have the chance of developing associated diseases such as hypertension, hyperlipidemia and obesity which may leads to metabolic complications of both clinical and experimental diabetes. The present study was carried out with novel synthesis of flavones and evaluated for antidiabetic activity in rats by inducing streptozotocin. The selection of STZ based on its action by inhibiting the secretion of pancreatic insulin due to damaging the $\beta$ cells which leads to develop Type 2 diabetes mellitus in rats. Those rats were treated with synthesized flavones for 21 days, which significantly act as a hypoglycemic drug.

Diabetes mellitus is a multifactorial disease, there is a risk in development of acute metabolic complication due to hyperglycemia results in ketoacidosis, hypoglycemia, hyperglycemic hyperosmolor nonketotic coma. Along with this, the development of chronic complications may occur results in hypertension, cardiac disorders, retinopathy, neuropathy, nephropathy and ulceration of foot. These metabolic fluctuations may also existed in the animals such as elevation of blood glucose level, total bilirubin and liver enzymes (SGOT, SGPT and SALP). In renal parameter, the total protein decreases which exist in elevation of blood urea level.

The study was carried out with consolidated synthesised flavones (F1, F2, F3, F5 and F8) were subjected for anti-diabetic activity in rats by inducing streptozotocin. The selection of STZ based on its action by inhibiting the secretion of pancreatic insulin due to damaging the $\beta$ cells which leads to develop Type 2 diabetes mellitus in rats. Those rats were treated with the related synthesized flavones for 21 days, which significantly act as a hypoglycemic drug. The blood glucose level was observed in normal rats and it is compared with diabetic and treated rats. After oral administration of synthesized flavones for 21 days were significantly reduced the blood glucose level compared with diabetic control rats. On $14^{\text {th }}$ and $21^{\text {st }}$ day the F1 and F8 were significantly decreases $(p<0.01)$ the blood glucose level compared with diabetic control. This indicates that which improve the metabolism significantly by comparing with the untreated rats. The liver and kidney plays an important role in elimination of metabolite and some toxic moieties. Liver and kidney dysfunction may lead to increase the biochemical substances in the blood stream due to administration of certain drugs. In diabetic condition, the level of transaminase in liver such as SGOT, SGPT and SALP were increases, which are highly active in absence of insulin. This is because of availability of amino acids in diabetic blood, which increases gluconeogenesis and ketogenesis those were observed in diabetes.

As per the above phenomena, the diabetic rats had significantly $(p<0.01)$ increased in transaminase and decreased in protein content than normal rats. After treatment with synthesised flavones had moderate significant decreases $(p<0.01)$ in liver enzyme activities and blood urea nitrogen as 
well as serum creatinine were significantly increases by compared with diabetic rats (Figure 3). The synthesized flavones F1 (benzo pyrone ring) and $\mathrm{F} 8\left(-\mathrm{OCH}_{3}\right.$ electron donating group) were significantly $(p<0.01)$ restores the liver and renal parameters compared with the diabetic rats.

\section{CONCLUSION}

Based on the result, the study should focus on the in vivo antidiabetic activity on selected synthesised flavones which possess good anti-diabetic activity. The selected synthesised flavones were F1, F2, F3, F5 and F8 were subjected for STZ induced antidiabetic activity. By which, the blood glucose level, liver and renal parameters were observed. The results showed that the compound F1 with basic ring structure of bezopyran ring and $\mathrm{F} 8$ with electron donating group $\left(-\mathrm{OCH}_{3}\right)$ substitution on benzopyrone ring were reduces the blood glucose level and also restores the liver and renal parameters for the treated rats significantly. These results suggested this study have not fulfil in establishing the precise mechanism and action of this molecule, hence this study should be proceed through molecular pharmacology and toxicological studies along with screening of therapeutic application of this drug. By which we can develop the potent drug in the management of diabetes mellitus.

\section{ACKNOWLEDGEMENT}

Authors acknowledge Narayan Institute of Pharmacy, Jamuhar Sasarm, Bihar, for providing necessary facilities to carry out the research work.

\section{CONFLICTS OF INTEREST}

There authors declare no conflict of interest.

\section{REFERENCES}

1. Mealey BL, Ocampo GL. Diabetes mellitus and periodontal disease. Periodontology. 2007;44(1):127-53.

2. Helaine E, Resnick M. In This Issue of Diabetes Care. Diabetes Care. 2013;36:1431-2.

3. Das S, Mitra I, Batuta S, Alam MN, Roy K, Begum NA. Design, synthesis and exploring the quantitative structure-activity relationship of some antioxidant flavonoid analogues. Bioorg Med Chem Lett. 2014;24(21):5050-4.

4. Cushnie TP, Lamb AJ. Recent advances in understanding the antibacterial properties of flavonoids. Int J Antimicrob Agents. 2011;38(2):99-107.
5. Liu HB, Wang ZL, Qiao YX, Zhou JJ. Flavonoids with aldose reductase inhibiting activity: Pharmacophore modelling and implications for mechanism. Act Phys Chim Sini. 2007;23:25-35.

6. Gonzalez R, Ballester I. Efects of flavonoids and other polyphenols on inflammation. Crit Rev Food Sci Nutr. 2011;51(4):331-62.

7. Nishiumi S, Miyamoto S. Dietary flavonoids as cancer preventive and therapeutic biofactors. Front Biosci. 2011;3:1332-62.

8. Unnikrishnan PS, Suthindhiran K, Jayasri MA. Alpha-amylase inhibition and antioxidant activity of marine green algae and its possible role in diabetes management. Pharmacogn Mag. 2015;11(Suppl 4):S511-5.

9. Moller DE. New drug targets for type 2 diabetes and the metabolic syndrome. Nature. 2001;414(6865):821-7.

10. Balaji RM, Jeyaram C, Sundaram KM, Ramasamy MS. Studies on Anti-diabetic Activity of Indian Medicinal Plants Using $\alpha$-Amylase and $\alpha$-Glucosidase Inhibitory Activity-A Pathway to Anti-diabetic Drugs. World J Med Sci. 2015;12(03):20712.

11. Mohan S, Nandhakumar L. Role of various flavonoids: Hypotheses on novel approach to treat diabetes. J Med Hypo Id. 2014;8(1):1-6.

12. Garcia LA, Guillamon E, Villares A, Rostagno MA, Martinez JA. Flavonoids as anti-inflammatory agents: Implications in cancer and cardiovascular disease. Inflamm Res. 2009;58(9):537-52.

13. Liu S, Li D, Huang B, Chen Y, Lu X. Wang, Y. Inhibition of pancreatic lipase $\alpha$-glucosidase, $\alpha$-amylase and hypolipidemic effects of the total flavonoids from Nelumbo nucifera leaves. J Ethnopharmacol. 2013;149(1):263-9.

14. Parasuraman S, Balamurugan S, Christapher PV, Petchi RR, Yeng WY, Sujithra J, et al. Evaluation of antidiabetic and antihyperlipidemic effects of hydroalcoholic extract of Leaves of Ocimum tenuiflorum (Lamiaceae) and Prediction of biological activity of its phytoconstituents. Pharmacognosy Res. 2015;7(2):156-65.

15. Wagner H, Farkas L. Synthesis of flavanoids, The flavanoids. Springer US. 1975;127-213.

16. Core AL, Hossain S, Cole AM, Phansteil O. Synthesis and bioevaluation of substituted chalcones, coumaranones and other flavonoids as anti-HIV agents. Bioorg Med Chem. 2016;24(12):2768-76.

17. Pramod S, Dasharath D, Ravi V, Pudukulathan K. Cyclization of 2'-hydroxychalcones to flavones using ammonium iodide as an iodine source-an eco-friendly approach. J Serb Chem Soc. 2013;78(7):909-16.

18. Ghasemi A, Khalifi S, Jedi S. Review - Streptozotocin-nicotinamide-induced rat model of type 2 diabetes. Act Physio Hung. 2014;101(4):408-20.

19. Dhanabal SP, Kokate CK, Ramanathan M, Elango K, Suresh B. The hypoglycemic activity of Coccinia indica Wight and its influence on certain biochemical parameters. Indian J Pharmacol. 2004;36(4):249-50.

20. Lowry $\mathrm{OH}$, Rosebrough NJ, Farr AL, Randall RJ. The original method. J Biol Chem. 1951;193:265-75.

21. Folin O, Wu H. A system of blood analysis. J Bio Chem. 1919;38:81-110.

22. Talke H, Schubert GE. Enzymatic Determination of Urea Using the Coupled Urease-GLDH Enzyme System. Mediat Inflamm. 1965:43:174-5. 